\title{
CHEMICAL SIGNALING BETWEEN GUAVA (Psidium guajava L., Myrtaceae) AND THE GUAVA WEEVIL (Conotrachelus psidii Marshall)
}

\section{SEÑALIZACIÓN QUÍMICA ENTRE LA GUAYABA (Psidium guajava L., Myrtaceae) Y EL PICUDO DE LA GUAYABA (Conotrachelus psidii Marshall)}

Alicia Romero-Frías ${ }^{1}$ José Maurício Simões-Bento ${ }^{2}$ Coralia Osorio ${ }^{1,3}$

\section{ABSTRACT}

Volatile organic compounds (VOCs) from guava (Psidium guajava L.) reproductive tissues (flower bud, open flower, petal fall, fruit setting, and fruit growth) were collected in situ during the day by headspace-solid phase microextraction (HS-SPME), and from flower bud and fruit setting by dynamic headspace (DHS). The samples were analyzed by GC-MS to separate and identify VOCs produced by guava, which potentially could attract the guava weevil (Conotrachelus psidii Marshall, Coleoptera: Curculionidae), one of the most important pests of guava plants in Colombia and Brazil. The terpenes $\beta$-caryophyllene, limonene, and copaene (tentatively identified) were present in all of the guava reproductive tissues, being the major constituents in flower bud and fruit setting, the two guava stages where C. psidii is commonly found. Additionally, the volatile compounds released by male and female insects were separately collected by HS-SPME, and comparatively analyzed by GC-MS. As result, some of volatile detected in the guava reproductive tissues were also released from insects. The behavioral response of the volatile blends and the above-mentioned compounds was studied in a Y-tube olfactometer bioassay, allowing confirming the presence of host kairomones in the guava reproductive tissues.

Key words: Semiochemicals, behavioral response, guava VOCs.

Departamento de Química, Universidad Nacional de Colombia, AA 14490, Bogotá, Colombia

2 Departamento de Entomologia e Acarologia, Universidade de São Paulo (USP-ESALQ), CP 09, 13418-900, Piracicaba-SP, Brazil

3 Author to whom correspondence should be addressed: C. Osorio. Telephone: +57-1-3165000, ext. 14452/14472. Fax: +57-1-3165220. E-mail: cosorior@unal.edu.co 


\section{RESUMEN}

Los compuestos orgánicos volátiles (VOCs) presentes en los tejidos reproductivos (yema floral, flor abierta, flor seca, fruto cuajado, fruto inmaduro) de la guayaba (Psidium guajava L.) se recolectaron durante el día in situ utilizando la técnica de headspace-micro extracción en fase sólida (HS-MEFS), y del fruto cuajado y la yema floral, por headspace dinámico (DHS). Las muestras se analizaron por CG-EM para separar e identificar los VOCs producidos por la guayaba, que potencialmente pueden atraer el picudo de la guayaba (Conotrachelus psidii Marshall, Coleoptera: Curculionidae), una de las plagas más importantes de guayaba en Colombia y Brasil. Los terpenos $\beta$-cariofileno, limoneno y el copaeno (identificado tentativamente) se encontraron en todos los tejidos reproductivos de la guayaba, siendo los mayoritarios en la yema floral y el fruto cuajado, los dos estados donde comúnmente se encuentra el C. psidii. Adicionalmente, los compuestos volátiles producidos por insectos adultos machos y hembras se recolectaron separadamente por HS-MEFS y se analizaron comparativamente por GC-EM. Como resultado se encontró que algunos de los compuestos volátiles detectados en los tejidos reproductivos de la guayaba fueron liberados también por los insectos. La respuesta de comportamiento frente a la mezcla de compuestos volátiles y a los compuestos puros mencionados anteriormente fue evaluada mediante bioensayos en un olfatómetro en Y, confirmando la presencia de cairomonas provenientes de los tejidos reproductivos de su hospedero.

Palabras claves: Semioquímicos, respuesta de comportamiento, VOCs de guayaba.

\section{INTRODUCTION}

Guava (Psidium guajava L., Myrtaceae) is a tropical fruit widespread worldwide, being highly cultivated in India, Pakistan, Mexico, Brazil, Colombia, Thailand, Egypt, Indonesia, Malaysia, USA, and Australia (Singh, 2011). In Colombia, the guava production averaged 1.3 million tons per year over the past five years (Ministerio de Agricultura y Desarrollo Rural de Colombia, 2012). The fruit is known by its pleasant and intense aroma (Steinhaus et al, 2008; Steinhaus et al, 2009), a low fat content, and a high pectin, fiber, minerals, essential amino acids, and vitamin C contents, which makes it a very healthy food and also a promising source of food value-added products (Osorio et al, 2011). However, one of the main limiting factors for its production in Colombia (Insuasty et al,
2007), Brazil (Silva-Filho et al, 2012), México (Tafoya et al, 2010), and Venezuela (Boscán de Martínez and Cásares, 1980) is the damage caused by insect pests, such as the guava weevil, Conotrachelus psidii Marshall (Coleoptera: Curculionidae), and C. dimidiatus, a related-species in México (Sánchez-Soto, 2011).

A protective role of volatile produced by wounded guava against the Asian Citrus psyllid (syn Diaphorina citri Kuwayama) has been suggested; thus VOCs released from crushed and intact guava leaves (Psidium guajava L.) were collected by using static headspace SPME and comparatively analyzed by GC-MS (Rouseff et al, 2008). Later, Onagbola et al. (2011) performed comparative experiments in laboratory olfactometers and in field, with and without 
guava leaf volatiles and with synthetic dimethyl disulphide (DMDS). They found that VOCs from guava leaves significantly inhibited attraction of $D$. citri to normally attractive host-plant (citrus) volatiles, and that field deployment of DMDS reduces densities of $D$. citri. In other study, behavioral and electrophysiological responses of males and females of the Mexican fruit fly Anastrepha ludens (Loew) to guava volatiles were investigated in laboratory assays. As a conclusion, it was established that males and females were attracted to a synthetic mixture of eightvolatile compounds identified in the plant, which demonstrated the importance of the VOCs in this insect-plant interaction (Malo et al, 2005).

Conotrachelus psidii Marshall (Coleoptera: Curculionidae) is one of the most important pests of guava plants. The adults of $C$. psidii are small dark brown weevils ( $6 \mathrm{~mm}$ long) with crepuscular habits. Adults emerge during a period of 20 to 30 days in the rainy season and survive up to 435 days under laboratory conditions. This aggressive pest causes irreparable damages (rottenness and petrifaction) inside the fruit due to the growing of larvae after female guava weevils oviposit in unripe fruits (Fig. 1). After fully-grown, larvae migrate to the soil and burrow it down to pupate, remaining there until weather conditions are favorable for the adult emergence. Insecticides do not control the infestation effectively because larvae are not killed due to their location inside the fruits or soil (Monroy and Insuasty, 2006). Silva-Filho et al. (2012) evaluated the olfactory responses of the guava weevil to the odours of green and ripened fruits, leaves, and flower buds of $P$. guajava in a Y-tube olfactometer. They reported that flower buds odors were attractive to $C$. psidii males suggesting the presence of host plant kairomones. However, none of the VOCs involved in the signaling process of guava weevil and its host have been identified, yet.

Based on the studies performed with the Mexican guava weevil (Conotrachelus dimidiatus), Tafoya et al. (2011) concluded that the use of guava volatile compounds as a lure can be a successfully alternative to control populations of the guava weevil. They suggested that insect pheromones should be identified to increase the efficiency of insect capture.
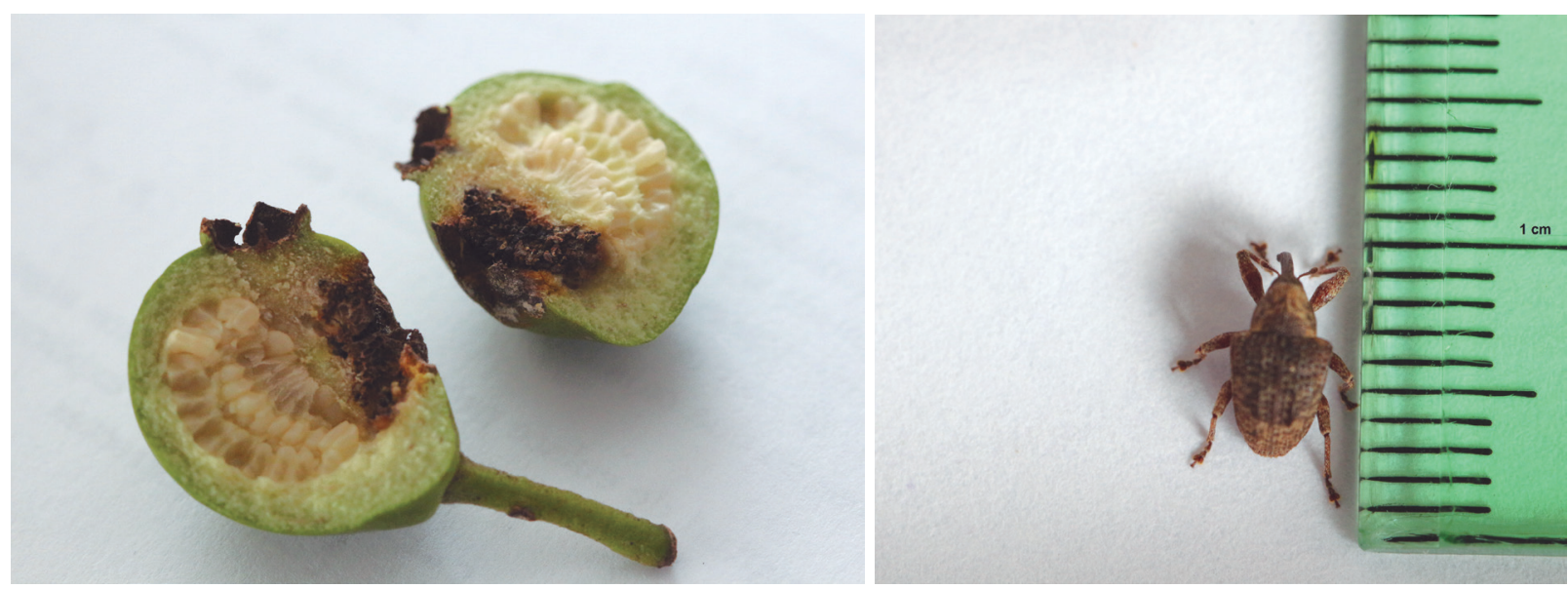

Figure 1. Damage of Conotrachelus psidii in guava fruit and photograph of adult insect. Photos: Edgar E. Daza, 2014. 


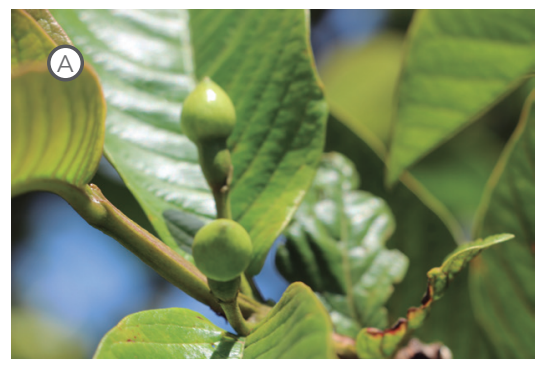

Semiochemicals can be successfully used to monitor and control pests as part of IPM (Insect Pest Management), due to lower costs, specificity, ease of use, and high sensitivity (Tewari et al, 2014). Thus, the aim of this work was to identify the volatile compounds released by five guava reproductive tissues and C. psidii adults, and determine through laboratory behavioral assays if VOCs may elicit the insect responses. This knowledge is necessary for the development of a semiochemical-based tool for the control of this pest in guava cultivars, what is a medium-term target.

\section{MATERIALS AND METHODS}

\section{Plant material}

The VOCs of five reproductive tissues, flower bud (containing embryonic flower), open flower, petal fall (pollinated flower), fruit setting (fully developed fruit just before the onset of maturation), and fruit growth ( $2.5 \mathrm{~cm}$ in diameter) (Fig. 2) (Salazar et al, 2006; Solarte et al, 2010) of Psidium guajava were collected in situ. VOCs collection was performed on non-infested trees located at commercial orchards in Moniquirá, Boyacá, Colombia (5 55'26" N, - 73 36' 9" W), periodically between April and May of 2011, 2012, and 2013. In each year, the analyses of each part were done by triplicate and on the same plants, and always during 9 am until 12 pm, when the largest volatile production from guava tissues was detected.

\section{Insects}

Conotrachellus psidii individuals were kept in plastic boxes at $20 \pm 2{ }^{\circ} \mathrm{C}$ and a relative humidity of $80 \pm 10 \%$ with pieces of green guava fruits as food. Sexes were distinguished using a stereoscope Nikon SMZ800 (Nikon corporation, USA) based on the observation of the antenna insertion on the rostrum, hair on the abdomen surface, and structure of the tibiae structure on the forelegs (Silva-Filho
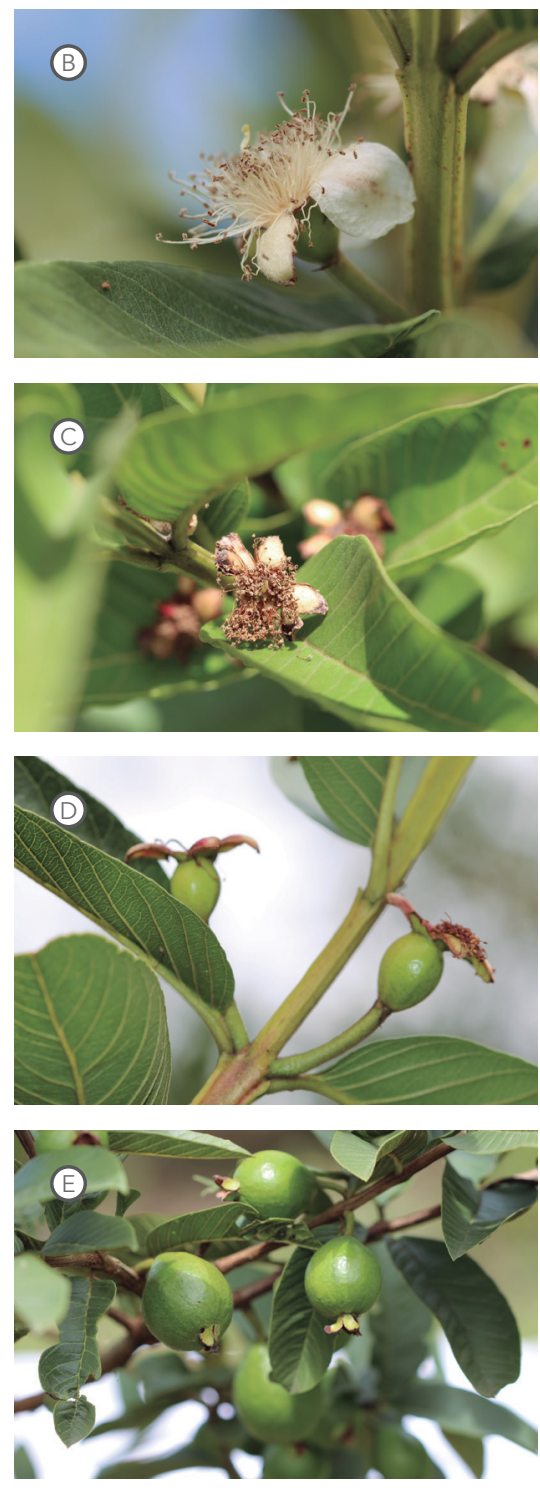

Figure 2. In situ guava (Psidium guajava L.) reproductive tissues a) flower bud, b) open flower, c) petal fall, d) fruit setting, and e) fruit growth. Photos: Edgar E. Daza, 2013. 
et al, 2007). The audible sound that male weevils produce by stridulating of their abdomen in contrast to females that do not do it helped during sex differentiation (Silva-Filho, 2005). The photoperiod was set to $12 \mathrm{h:12} \mathrm{h} \mathrm{L}: \mathrm{D}$. The insect colonies were established from guava weevil adults of unknown age and mating status collected between April to July 2013, November to December 2013, and May to June 2014, by using beating tray method after shaking branches of the guava plants, from a managed crop located in the Las Delicias (Puente Nacional, Santander, Colombia). The species Molytinae, Conotrachelini, Conotrachelus psidii Marshall (1922), was confirmed by the taxonomist Dr. Sergio Vanin, from the Instituto de Biociências (Universidade de São Paulo, Brazil).

\section{Volatile collection from guava tissues}

Volatile compounds were collected in situ by using two different methodologies, headspace-solid phase microextraction (HS-SPME), and dynamic headspace collection (DHS) using polymer based sorbents (Tholl et al, 2006) in order to obtain extracts to test with the insects. For HS-SPME, two parts of each guava phenological phase were enclosed in polypropylene cups (355 mL, Darnel-Ajover, USA) with lids Teflon-lined, and for each case a 50/30 $\mu \mathrm{m}$ divinylbenzene/carboxen/polydimethylsiloxane (DVB/CAR/PDMS) solid phase microextraction (SPME) fiber (Supelco, Bellefonte, PA) was manually inserted. After $3 \mathrm{~h}$, the SPME fibers were removed and carefully transported at $0^{\circ} \mathrm{C}$ to the laboratory for GC-MS analyses. Analyses of background volatiles were performed on unexposed SPME fiber and with environmental bag/air volatiles.

For dynamic headspace (DHS) collection, under controlled environmental conditions, each guava phenological phase were enclosed in polypropylene cups (500 mL, Darnel-Ajover, USA) with lids, in an inverted assembly. Fragrant headspace air of flower bud and green guava fruit tissues were swept through a cartridge trap packed $(10 \mathrm{~cm} \times 0.5 \mathrm{~cm}$ i.d) with the analytical polymer adsorbent HayeSep D 80/100 (DVB, Supelco, Bellefonte, PA), during 3h. Previously to the establishment of dynamic equilibrium process to trap VOCs released by guava tissues onto the adsorbent, incoming air supplied by the vacuum pump (GAST manufacturing Inc, USA) was filtered through charcoal. The sampling flow rate was $100 \mathrm{~mL} / \mathrm{min}$. After trapping, VOCs were eluted with $300 \mu \mathrm{L}$ of hexane HPLC grade (Merck, Darmstadt, Germany); then the sample was concentrated to about $50 \mu \mathrm{L}$ volume under a gentle flow of nitrogen to be analyzed by GC-MS.

\section{Volatile collection from insects}

Volatile compound released by C. psidii adults were collected in laboratory by using either headspace-solid phase microextraction (HS-SPME). Before the extraction, the weevils were deprived of food during $24 \mathrm{~h}$ in a room free from odorants and placed in $100 \mathrm{~mL}$ glass flasks. The volatile compounds released from each gender were separately collected on a DVB/CAR/PDMS fiber (50/30 $\mu$ m thickness, Supelco, Bellefonte, PA, USA) for $12 \mathrm{~h}$ during the scotophase, because the activity of insects were found at night. These analyses were done by triplicate with different insects ( 10 males and 10 females) each time. Analyses of background volatiles were performed with SPME fiber in the flask without insects. Blank experiments were performed without insects in the same conditions above-mentioned.

\section{Volatile analyses}

Volatile collected by HS-SPME either from guava tissues or insects were desorbed into the injection port of a Shimadzu GC17A coupled to a mass selective detector QP5050 (Shimadzu, Tokyo, Japan). Desorption time was set at $5 \mathrm{~min}$. Two capillary columns, RTX-5 and DB-FFAP and (each $30 \mathrm{~m} \times 0.32 \mathrm{~mm}$ i.d., $0.25 \mu \mathrm{m}$ 
film thickness; Restek, Bellefonte, PA, USA, and J\&W Scientific, Folsom, CA, USA, respectively) were used. The column oven was programmed from $40^{\circ} \mathrm{C}$ (after $1 \mathrm{~min}$ ) to $300^{\circ} \mathrm{C}$ at $4^{\circ} \mathrm{C} / \mathrm{min}$ for RTX-5, and until $250^{\circ} \mathrm{C}$ for DB-FFAP column, and finally held it for $10 \mathrm{~min}$. For the volatile compounds released from insects, the column was held at $50^{\circ} \mathrm{C}$ for $1 \mathrm{~min}$, then raised to $250^{\circ} \mathrm{C}$ at $7^{\circ} \mathrm{C} / \mathrm{min}$ and maintained at that temperature for 10 $\mathrm{min}$. The injector temperature was fixed at $250^{\circ} \mathrm{C}$ for the DB-FFAP and at $300^{\circ} \mathrm{C}$ for the RTX- 5 column, using helium as carrier gas at $1.5 \mathrm{~mL} / \mathrm{min}$. The injection port was used in splitless mode and the temperature was maintained at $250^{\circ} \mathrm{C}$. Linear retention indices (LRI) were calculated according to the Kovats method using a mixture of $n$-alkanes as external references. Mass spectral identification was completed by comparison with either authentic reference standards or spectra from commercial mass spectral databases (WILEY and EPA/NIH). MS-data in the electron ionization (EI) mode were recorded in a mass range 30-350 $u$, with electron energy of $70 \mathrm{eV}$ and processed by Class 5000 v 2.2 MS-Workstation software.

\section{Chemicals}

The following compounds were purchased from Sigma-Aldrich (Taufkirchen, Germany) and used as reference odorants: (Z)-3-hexenyl acetate, limonene, 2-nonanone, nonanal, 2-phenyl ethanol, cis-3-hexenyl butyrate, decanal, 2-undecanone, cis-3-hexenyl hexanoate, $\beta$-caryophyllene, $\alpha$-humulene, $\beta$-farnesene, aromadendrene, and heptadecane. n-Alkane mix $\left(\mathrm{C}_{8}-\right.$ $\mathrm{C}_{26}$ ) was acquired from Merck, Darmstadt, Germany.

\section{Olfatometric bioassays with semiochemicals}

The behavioral response of $C$. psidii was evaluated by testing the flower bud and fruit setting volatile blends, as well as the synthetic compounds limonene (mixture of stereoisomers) and $\beta$-caryophyllene, both prepared at a concentration of $100 \mu \mathrm{g} / \mathrm{mL}$ in hexane (HPLC grade, Merck, Darmstadt, Germany).
Bioassays were performed in a dual choice $Y$ tube olfactometer operated with a pre-humidified and charcoal filtered airflow at a flow of $1 \mathrm{~L} / \mathrm{min}$. Odour propagation simulation tests were performed to visualize the plume distribution inside the system. The olfactometer consisted of a Y-shaped glass tube of $3.5 \mathrm{~cm}$ diameter, $20 \mathrm{~cm}$ in length, 10 $\mathrm{cm}$ of arms and a $90^{\circ} \mathrm{Y}$ angle. All the treatments were performed during the scotophase with a red light to avoid any interference of the white light, at room temperature $\left(20 \pm 2^{\circ} \mathrm{C}\right)$ and a relative humidity of $80 \pm 10 \%$.

One week before each assay, Conotrachelus psidii adults (males and females, with a number varying between 30 to 40 individuals) were collected, placed in plastic flasks, and deprived of food in a room free from odorants for $24 \mathrm{~h}$ before the olfatometric bioassay. In all cases, different insects were used for each test. Age and mating status of the insects were not controlled. The insects (male or female) were introduced one by one into the base tube of the olfactometer, and its behavior was observed for $5 \mathrm{~min}$; after that, the next individual was evaluated until the entire test finished. A positive choice for the odor source in one of the two arms was considered when an insect crossed the choice line, went all over $5 \mathrm{~cm}$ of that arm, and remained there for at least $2 \mathrm{~min}$. Individuals that did not make any choice during this time were excluded from the statistical analysis. The position of olfactometer was alternated after each replicate to avoid positional bias. For each replicate, a new piece of braided cotton roll $(0.5 \times 0.5 \mathrm{~cm}$; Richmond Dental, Charlotte, NC, USA) loaded with the solutions of tested compounds was used. The evaporation time before starting the tests was 10 seconds. Odour sources (2 $\mu \mathrm{L}$ ) were tested against hexane HPLC grade (Merck, Darmstadt, Germany) as solvent control and the insect response compared after the stimuli. After each test, all components of the olfactometer was 
cleaned with a detergent solution (Extran alkaline, Merck, KGaA, Darmstadt, Germany), then rinsed with acetone, and dried at $100^{\circ} \mathrm{C}$ for $30 \mathrm{~min}$ to keep away from cross contamination.

\section{Statistical analysis}

Y-tube olfactometer data were analyzed by chisquare tests to compare between possible binary $C$. psidii responses. The null hypothesis was considered 50:50 distribution. Data analyses were performed using WinSTAT® for Excel 2007 (V. 2012.1.0.84).

\section{RESULTS AND DISCUSSION}

\section{Analysis of semiochemicals from guava reproductive tissues}

The VOCs from guava reproductive tissues were analyzed by GC-MS and their relative concentrations determined by the area percentage in GC analysis (Table 1). Taking into account that the fiber composition determines the selectivity of the analysis, four commercially available fibers were tested as part of the preliminary assays (PDMS, $100 \mu \mathrm{m}$; PDMS/DVB, $65 \mu \mathrm{m}$; CAR/PDMS, $75 \mu \mathrm{m}$; and PDMS/ DVB/CAR, 50/30 $\mu \mathrm{m})$. The last one was chosen because it retained the highest number of volatile components. Sixteen VOCs were detected in all of the guava tissues and fourteen of them were identified by comparison of their retention indexes and mass spectra with those of corresponding commercially available standards.

The largest number of VOCs was detected from open flower in comparison with the other guava tissues. It is known that the highest diversity and abundance of VOCs is released predominantly from flowers and their formation is spatially regulated.

Aliphatic esters ( $C_{6}$-type volatiles) such as, cis3-hexenyl acetate, cis-3-hexenyl butyrate, and cis3-hexenyl hexanoate were only detected in the flower, as well as the more polar compounds, 2-nonanone, 2-undecanone, decanal, and 2-phenyl ethanol. In the other tissues, mono and sesquiterpenes were the most predominant VOCs. The sesquiterpenes $\beta$-caryophyllene, and copaene were the major VOCs detected by HS-SPME in the flower bud and fruit setting, being also detected in the other evaluated guava tissues. Limonene was also present in all of the guava tissues; it had been previously identified in guava leaves by using the same technique (Rouseff et al, 2008). Qualitative and quantitative composition of VOCs in guava open flower is clearly different from other parts of the plant; this result could be related to the fact that guava weevils were not found on the flowers during their field collection.

It is known that male guava weevils are selectively attracted by either flower bud or fruit setting VOCs (Silva-Filho et al, 2012), so dynamic headspace (DHS) was used to obtain volatile extracts from these tissues. During preliminary experiments, Hayesep D (DVB) polymer extracted VOCs better in comparison to Porapak Q (4-ethylstyrene-DVB) and ORBO-32 (charcoal adsorbent tubes). Except the sesquiterpenes selinene and chamigrene (tentatively identified), the volatile profiles collected with HS-SPME and DHS extracts were the same.

The interaction between phytophagous insects and their hosts is mediated by VOCs that are synthesized during plant metabolism and released into the environment. Thus, VOCs often plays a role as sensory cues that define host specificity (food or oviposition site) (Marín-Loaiza and Céspedes, 2007). Silva-Filho et al. (2012) reported guava weevils olfactory-response in a Y-tube olfactometer to odors in guava flower buds; however, they did not elucidated the chemical structure of those volatile compounds. In this work, some of volatile released from insects (Table 1) were also detected in the guava reproductive tissues; specifically, $\beta$-caryophyllene was released from male and female C. psidii adults. This fact could be related to a role of $\beta$-caryophyllene either as precursor of aggregation 


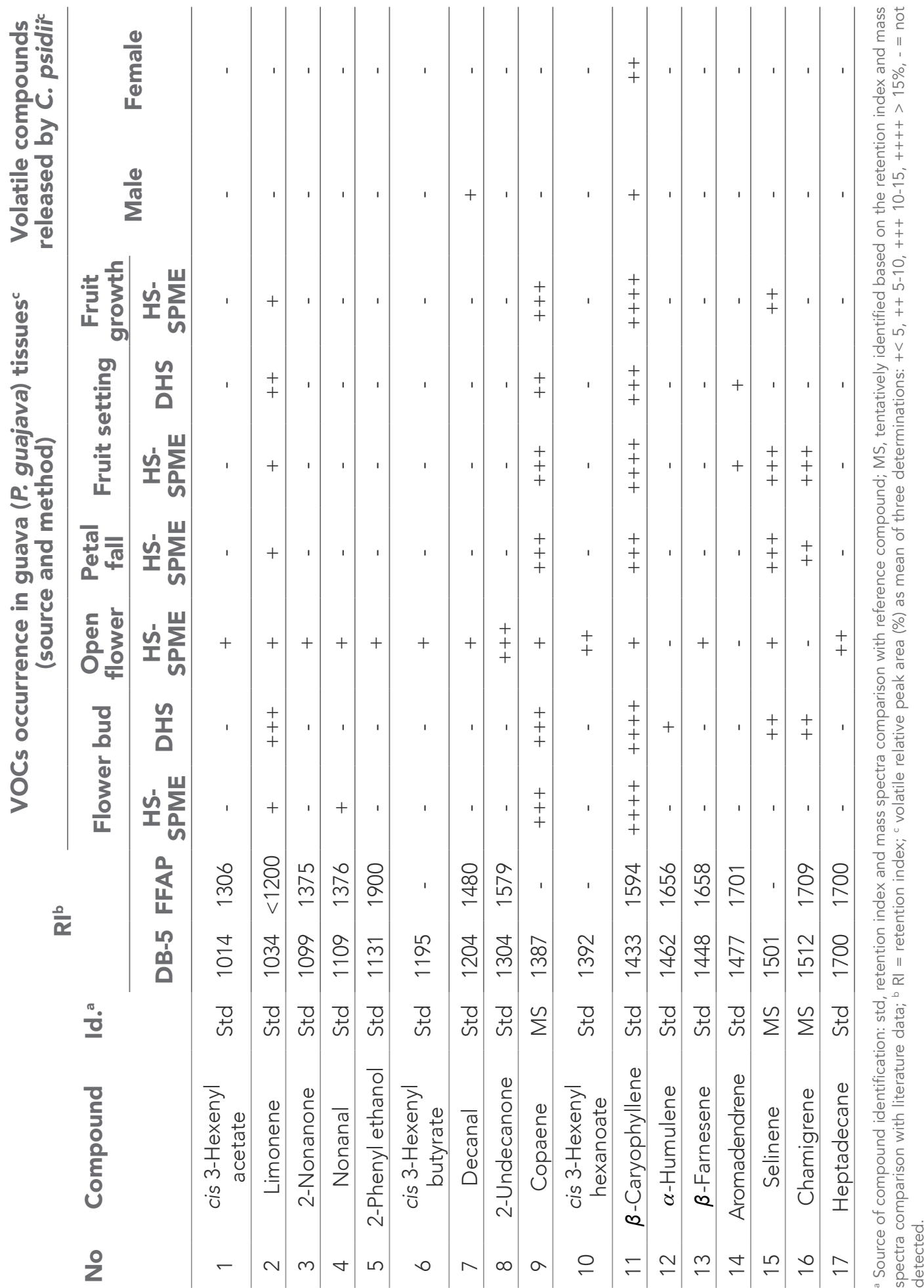


pheromone or as semiochemical in C. psidii, but experiments are needed to confirm this hypothesis.

Response of Conotrachelus psidii to VOCs in Ytube olfactometer

The responses of $C$. psidii males and females in a Y-tube olfactometer when they were stimulated with odour sources are shown in Fig. 3. The attraction of males and females to the natural flower bud and fruit setting volatile blends was evident $(p<0.05)$, due to the availability of a food source. The results showed that limonene at $100 \mu \mathrm{g} / \mathrm{mL}(2 \mu \mathrm{L})$ elicited a significant attractant response from the weevils, attracting females and males $(p<0.05)$. This result, suggests that $C$. psidii insects could use limonene as a kairomone to locate suitable hosts for feeding and oviposition. Limonene has been reported as a semiochemical for the curculionid Conotrachelus nenuphar (Herbst) (Piñero and Prokopy, 2003), and it has also been applied in traps for controlling the curculionid Hylobius pales L. (Siegfried, 1987).

Guava weevils were not attracted by the $\beta$-caryophyllene in the Y-tube olfactometer at the dose tested. The fact that insect response to a particular volatile compound can be markedly influenced by the concentration of that compound is known in chemical ecology as it has been reported for other weevil species (Dickens, 1986). For instance, Leskey et al. (2001) found that C. nenuphar was attracted to several plum volatiles when tested at low doses, but it was repelled at high doses in the laboratory. However, when the compounds were evaluated in field conditions using doses as those used in the laboratory most of them were attractive to $C$. nenuphar. The authors suggested the repellence of compounds when tested at the highest doses in the laboratory might be due to artifacts caused by their evaluation in enclosed chambers over short distances. Thus, to confirm that the concentration is a determinant factor during the behavioral response of the weevil, new experiments using different concentrations of $\beta$-caryophyllene need to be done.

The results here reported suggest that the infestation of Colombian guava crop by Conotrachelus psidii insects is mediated by host plant kairomones. These results have been reported in other curculionids, for instance, limonene for Conotrachelus

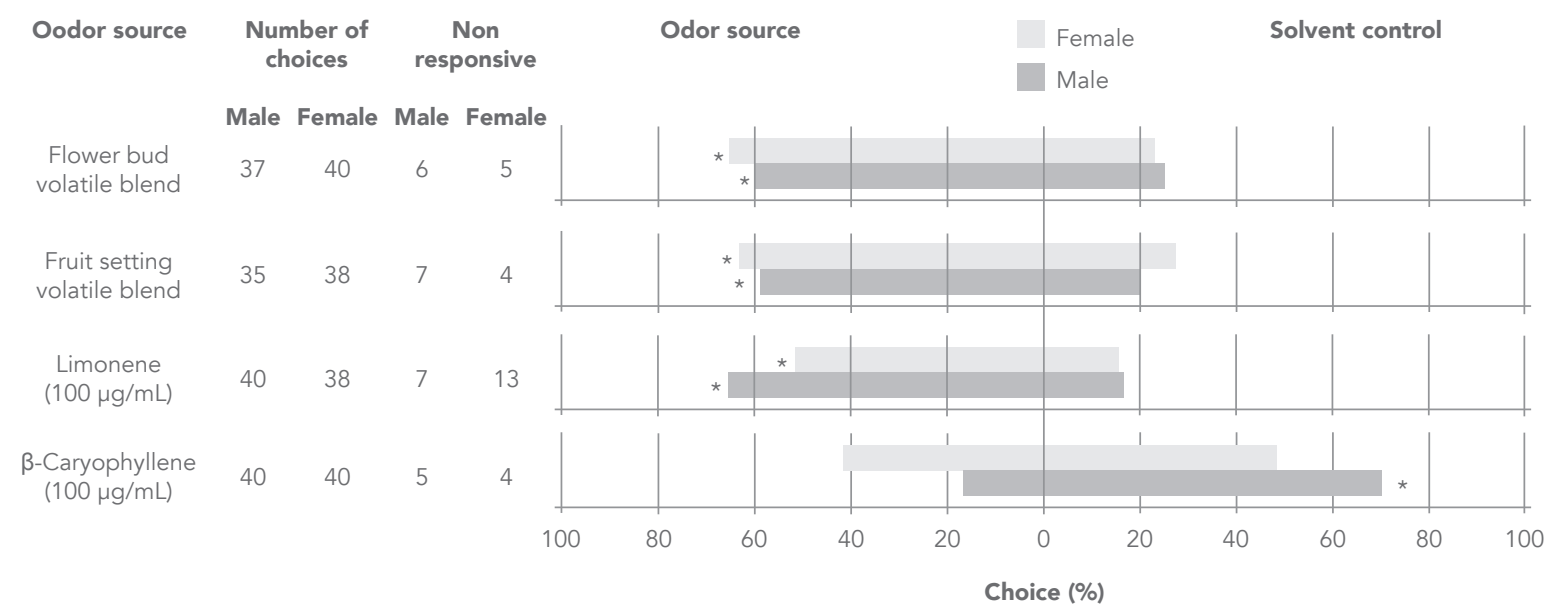

Figure 3. Responses of individual male and female C. psidii adults to treatments in a Y-tube olfactometer. In each experiment the asterisk (*) indicate a statistically significant differences. Binomial test $(P<0.05)$. 
nenuphar (Leskey et al, 2001), and $\beta$-caryophyllene for Conotrachelus dimidiatus (Contreras-Montañez and Tafoya, 2008). This information provides an essential component for the development of an effective IPM program for this pest in guava.

\section{ACKNOWLEDGMENTS}

The authors are grateful to Laura Marcela Machuca, Dra. Alicia Lucía Morales, Sven Alarik, Johnny Ruíz, Dr. Edgar Eduardo Daza, and the staff of Centro de Gestión Agroempresarial del Oriente (SENA, Velez, Santander, Colombia) for their valuable cooperation during the sampling of plants and insects in the countryside of Santander, Colombia. Dra. Diana Cristina Sinuco from Department of Chemistry, and Dra. Argenis Bonilla from Department of Biology Universidad Nacional de Colombia are thanked for tunning the GC-MS equipment and for lending the stereoscope, respectively. Dra. Katja Poveda is thanked for kindly lending the DHS field system. This research was supported by grants from Dirección Nacional de Investigación (DIB) - Universidad Nacional de Colombia-Sede Bogotá, Fundación Para la Promoción de la Investigación y la Tecnología (Banco de la República, Convenio 201406) and INCT Semioquímicos na Agricultura (Fapesp and CNPq). Alicia Romero-Frías thanks financial support of a scholarship from Departamento Administrativo de Ciencia, Tecnología e Innovación (COLCIENCIAS).

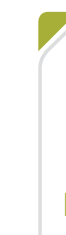

\section{REFERENCES}

1. Boscán de Martínez N, Cásares R. 1980. El gorgojo de la guayaba Conotrachelus psidii Marshall (Coleoptera: Curculionidae). I. Evaluación de daños. Agronomía Tropical 30 (1-6): 77- 83.

2. Contreras-Montañez K, Tafoya F. 2008. Aislamiento de atrayentes naturales en el picudo de la guayaba Conotrachelus dimidiatus. P. 900-904. In Estrada VEG (Ed.) Entomología Mexicana, Vol. 8.

3. Dickens JC. 1986. Orientation of boll weevil, Anthonomus grandis Boh. (Coleoptera: Curculionidae), to pheromone and volatile host compound in the laboratory. Journal of Chemical Ecology, 12 (1): 91-98.

4. Insuasty O, Monroy R, Díaz A, Bautista. J. 2007. Manejo integrado del picudo de la guayaba Conotrachelus psidii, Marshall en Santander. Corporación Colombiana de Investigación Agropecuaria. Corpoica, Barbosa-Santander. Editorial Produmedios.

5. Leskey TC, Prokopy RJ, Wright SE, Phelan PL, Haynes LW. 2001. Evaluation of individual components of plum odor as potential attractants for adult plum curculios. Journal of Chemical Ecology, 27 (1): 1-17.

6. Malo EA, Cruz-Lopez L, Toledo J, Del Mazo A, Virgen A, Rojas JC. 2005. Behavioral and electrophysiological responses of the Mexican fruit fly (Diptera: Tephritidae) to guava volatiles. Florida Entomologist, 88 (4): 364-371.

7. Marín-Loaiza JC, Céspedes CL. 2007. Compuestos volátiles de plantas, origen, emisión, efectos, análisis y aplicaciones al agro. Revista Fitotecnia Mexicana, 30 (4): 327-351. 
8. Ministerio de Agricultura y Desarrollo Rural de Colombia. 2012. Anuario Estadístico de Frutas y Hortalizas 2007-2011 y sus Calendarios de Siembras y Cosechas. Dirección de Política Sectorial. Grupos de Sistemas de Información, p. 71-73.

9. Monroy R, Insuasty O. 2006. Biología del picudo de la guayaba Conotrachelus psidii (Marshall) (Coleoptera: Curculionidae). Revista Corpoica- Ciencia y Tecnología Agropecuaria, 7 (2): 73-79.

10. Onagbola EO, Rouseff RL, Smoot JM, Stelinski LL. 2011. Guava leaf volatiles and dimethyl disulphide inhibit response of Diaphorina citri Kuwayama to host plant volatiles. Journal of Applied Entomology, 135 (6): 404-414.

11. Osorio C, Forero DP, Carriazo JG. 2011. Characterisation and performance assessment of guava (Psidium guajava L.) microencapsulates obtained by spray-drying. Food Research International, 44 (5): 1174-1181.

12. Piñero JC, Prokopy RJ. 2003. Field evaluation of plant odor and pheromonal combinations for attracting plum curculios. Journal of Chemical Ecology, 29 (12): 2735-2748.

13. Rouseff RL, Onagbola EO, Smoot JM, Stelinski LL. 2008. Sulfur volatiles in guava (Psidium guajava L.) leaves: Possible defense mechanism.
Journal of Agricultural and Food Chemistry, 56 (19): 8905-8910.

14. Salazar DM, Melgarejo P, Martínez R, Martínez JJ, Hernández F, Burguera M. 2006. Phenological stages of the guava tree (Psidium guajava L.). Scientia Horticulturae, 108 (2): 157-161.

15. Sánchez-Soto S. 2011. Conotrachelus dimidiatus champion (Coleoptera: curculionidae): el picudo de la guayaba (Psidium guajava L.) en Tabasco, México. Boletín del Museo de Entomología de la Universidad del Valle (Cali, Colombia), 12, 17-18.

16. Siegfried B. 1987. In-flight responses of the pales weevil, Hylobis pales (Coleoptera: Curculionidae) to monoterpene constituents of southern pine gum turpentine. Florida Entomologist, 70 (1): 97-102.

17. Silva-Filho G. 2005. Semioquímicos envolvidos na interação gorgulho da goiaba (Conotrachelus psidii Marshall) - goiabeira (Psidium guajava L.). Teses de mestrado, Centro de Ciências e Tecnologias Agropecuárias, Univerdidade Estadual do Norte Fluminense Darcy Ribeiro - UENF.

18. Silva-Filho G, Bailez O, Viana-Bailez AM. 2007. Dimorfismo sexual do gorgulho-da-goiaba Conotrachelus psidii Marshall (Coleoptera: Curculionidae). Neotropical Entomology, 36 (4): 450-524. 
19. Silva-Filho G, Bailez OE, Viana-Bailez AM. 2012. Olfactory responses of Conotrachelus psidii (Coleoptera: Curculionidae) to hosts and conspecific odors. Revista Colombiana de Entomología, 38 (2): 196-199.

20. Singh SP. 2011. Guajava (Psidium guajava L.). p 213-245. In Yahia E (Ed.). Postharvest Biology and Technology of Tropical and Subtropical Fruits. Volume 3: Cocona to Mango. Woodhead Publishing Ltd., Cambridge, UK.

21. Solarte M, Insuasty O, Melgarejo L. 2010. Calendario fenológico de la guayaba en la hoya del Río Suárez. p 59-82. In Morales AL, Melgarejo LM (Eds.) Desarrollo de Productos Funcionales Promisorios a partir de la Guayaba (Psidium guajava L.) para el Fortalecimiento de la Cadena Productiva, Editorial Panamericana: Bogotá DC, Colombia, http://www.bdigital. unal.edu.co/8536/4/04_Parte_01_Cap02.pdf.

22. Steinhaus $M$, Sinuco D, Polster J, Osorio C, Schieberle P. 2008. Characterization of the aroma-active compounds in pink guava (Psidium guajava L.) by application of the aroma extract dilution analysis. Journal of Agricultural and Food Chemistry, 56 (11): 4120-4127.

23. Steinhaus M, Sinuco D, Polster J, Osorio C, Schieberle P. 2009. Characterization of the key aroma compounds in pink guava (Psidium guajava L.) by means of aroma re-engineering experiments and omission tests. Journal of Agricultural and Food Chemistry, 57 (7): 2882-2888

24. Tafoya F, Perales-Segovia C, González-Gaona E, Calyeca-Cortero HG. 2010. Fruit damage patterns caused by ovipositing females of Conotrachelus dimidiatus (Coleoptera: Curculionidae) in guava trees. Psyche, article ID 819532, 4 pages, doi:10.1155/2010/819532.

25. Tafoya F, Velasco-Olvera J, Perales-Segovia C, González-Gaona E, Escoto-Rocha J. 2011. Evaluación de compuestos volátiles para estimar poblaciones del picudo de la guayaba Conotrachelus dimidiatus. Acta Universitaria. Universidad de Guanajuato, 21 (4), 65- 69.

26. Tewari S, Leskey TC, Nielsen AL, Piñero JC, Rodríguez-Saona CR. 2014. Use of pheromones in insect pest management, with special attention to weevil pheromones. p. 141-168. In Abrol DP (Ed). Integrated Pest Management: Current Concepts and Ecological Perspectives. Abrol, D. P., Ed.; Elsevier, Chapter 9.

27. Tholl D, Boland W, Hansel A, Loreto F, Rose U, Schnitzler J. 2006. Practical approaches to plant volatile analysis. The Plant Journal, 45 (4): 540-560. 